\title{
RESTORATION, NOT RENEWAL: FROM NAZI TO FOUR-POWER OCCUPATION - THE DIFFICULT TRANSITION TO DEMOCRACY IN AUSTRIA AFTER 1945
}

\author{
GÜNTER BISCHOF \\ University of New Orleans, New Orleans, LA, \\ USA \\ "[T]he Austrian tragedy ... consisted in the fact that the democrats \\ weren't sufficiently patriotic Austrians, while the Austrian patriots \\ in their turn weren't democratic enough."
}

\section{Introduction}

It is notoriously difficult to measure the rootedness of democracy in a nation. What ought to be our yardstick for success in democratic governance - the depth of civil society? the liveliness of grass roots politics in political culture? voter participation in campaigns and the electorate's turn-out in elections? adherence to human rights and tolerance in political discourse? What are our models - an abstract theoretical paragon of a model democracy constructed by philosopher kings, or American and British democracy, the oldest and most successful practicing democracies in the world?

Reestablishing democratic governance after long periods of totalitarian repression represents a particularly daunting task. In 1945 Austria after five years of Austro-Fascism and seven years of Nazi dictatorship was not so different from Hungary in 1990 after more than 40 years of communist totalitarianism. The long dark period of repression and intimidation and enforced non-participation in the political process made people's instincts to practice grass roots politics and civil society whither. Sheer survival forced people to levels of collaboration with totalitarian regimes, which dulled their will for political action and hobbled their respect for the arena of contentious democracy. Both denazificiation in Austria after 1945 and, for want of a better word "decommunization" ("lustrace" in Czechoslovakia, uncovering the Stasi regimes in the former German Democratic Republic and Poland, etc.) after 1989 were, widely resented by the implicated populations and produced new "victims myths." How to purge a body politic of the ghosts of the past? $?^{2}$

Looking at the case study of the Republic of Austria and its difficult transition from National Socialist ("Nazi") dictatorship to democracy after 1945 we need an 
analytical tool that allows us to observe the process of democracy successfully taking roots after World War II. I propose to do this introducing some comparisons to the West German transition after 1945. ${ }^{3}$ As far as suitable comparisons go, these two Central European neighbors offer similar trajectories of transitions from totalitarian rule to democratic governance under the tutelage of four-power occupation regimes. There are major differences in the history, political culture and traditions of these two countries, but we cannot dwell on these.

We will introduce some analytical tools of the German scholars Hermann-Josef Rupieper and Anselm Doering-Manteuffel about the genesis of postwar West German democracy to an analysis of the Austrian transition. ${ }^{4}$ Rupieper has looked at the process of restoration and/or reform in the reestablishment of West German democracy and uses the inclusion of German emigrés and resistance fighters in the reconstruction of the Federal Republic of Germany - they were the conscience

of their nation and provide a yardstick to observe an open mind for reform; Rupieper has also investigated the seriousness of denazification and reeducation as a measure of purging the old regime - the popular acceptance of liberal democracy indicated the willingness to welcome a radical new beginning. Behind all of this looms the question of continuities and discontinuities with the pre-World War II era after 1945. Was there a new beginning in 1945 - a "zero hour" ("Stunde Null")? While Rupieper has closely studied the emergence of the Federal Republic in the years 1946 to 1952 , Doering-Manteuffel takes a longer perspective and makes a crucial distinction between the establishment of "formal democracy" in the 1950s and the more important growth of liberal democracy ("inner democracy") in the 1960s. ${ }^{5}$

\section{The Genesis of the Second Austrian Republic after World War II}

\section{Restoration, Not Reform: No "Stunde Null"}

In 1945 the defeated Germany experienced total control by the four-power occupation of the Soviet Union, United States, Great Britain, and France. The noted constitutional scholar Carl J. Friedrich called Allied control a "constitutional dictatorship." The emergence of party life and a free press was heavily circumscribed. Grass roots local control emerged slowly in 1946; in 1947 West Germans began to participate more directly in building democracy and public life. In 1948 West Germans began drafting a constitution, and in the fall of 1949 they elected their first national government. ${ }^{6}$

The trajectory of (re)building a new republic in Austria was very different. The Allies gave the "liberated" Austrians much more political leverage than the de- 
feated Germans to reconstitute their democratic institutions. The basic American planning document from 1944 stated that Austria would be accorded "different treatment from that applied to Germany" and the Austrian people would be permitted "a voice in the determination of their future status." " This preferred treatment of liberated Austria had the consequence that the formal institutions of democratic governance emerged in 1945, much more quickly than in defeated Germany. This gave the Austrians a huge jump start in reestablishing their state and nation (scholars have called it Austria's "Vorsprung an Staatlichkeit").

Considerable continuity prevailed among the political elites of the First and the Second Republic. ${ }^{8}$ Even before the liberation of Austria from Nazi Germany was completed and the war ended, the Provisional Government led by Karl Renner proclaimed a new Austrian Republic from the Ballhausplatz on 27 April 1945. Renner's "declaration of independence" informed the world about the reestablishment of the democratic Republic of Austria and the reinstitution of the Constitution of 1920. ${ }^{9}$ This Provisional Renner Government operated as a broad "national unity" Conservative-Socialist-Communists three-party coalition. While the liberation of Vienna by the Red Army was still afoot, the conservative Christian People's Party and the Socialist Party had emerged in the early days of April 1945 largely through efforts of elder statesmen such as Karl Renner and Leopold Kunschak (ÖVP) and a younger generation of party hacks from the entrenched prewar political camps. Renner as a founder and first Chancellor of the First Austrian Republic was the prime example of the restoration of some of the prewar political elites as patres patriae. Next to Renner, Julius Raab and Leopold Figl in the ÖVP, as well as Adolf Schärf and Oskar Helmer in the SPÖ, had been politically active before the war. Raab, for example, had been a member of the last Schuschnigg Cabinet in 1938. The conservative-Christian People's Party (ÖVP) harbored many politicians like Felix Hurdes and Heinrich Drimmel who had supported the Austro-fascist regime and never explicitly renounced this anti-democratic heritage of the prewar Christian Social Party. Leopold Figl was one of the few prominent members of the Renner government to have spent most of the war in Nazi concentration camps, Schärf sat the war out in his Vienna "inner exile." Karl Gruber (ÖVP) was the only prominent resistance fighter against Nazism to join the Renner government when it came to govern all of Austria in the fall of 1945. Communist leaders such as Ernst Fischer were directly flown in from Moscow to reconstitute the Communist Party - the third party in the provisional Renner coalition. There was a strict prohibition for a party to be formed in 1945 from the old nationalist pro-German camp since Austria's most prominent Nazis hailed from this "third" camp, which in 1949 would start its own "fourth" party. The Western Allies considered the Renner Government a "Soviet puppet regime," similar to other such regimes established by the Red Army in Eastern Europe after 
liberation. They only recognized it in late October 1945. Until then the Renner government had no authority beyond the Soviet zone of occupation and was totally isolated from the Western occupation zones. ${ }^{10}$

A strong sense of a new beginning prevailed in these political elites, who created the myth of the "Wiederaufbaugeneration." The founding fathers' myth of a "new beginning" ("zero hour") - Austrians single-handedly and without outside support rebuilding both their polity and economy from the rubble of World War II - prevailed until the 1970s. ${ }^{11}$ The reality is much more complex than this founding myth of the Second Austrian Republic. Most historians today agree that there was no "Stunde null" in Austria! ${ }^{12}$ The Austrian diplomat Josef Schöner called Austria's beginning in April/May 1945 a return to the First Republic ("Rückbruch"). Schöner was an archetypal representative of his colleagues in the Foreign Ministry and much of the higher federal bureaucracy. Many had served under the Dollfuss and Schuschnigg regimes and lost their job in 1938 (or worse, went to concentration camps), yet considered the "elimination" of democracy necessary in 1933/4 "to prevent worse things to happen." 13 Some of the higher officials who had "done their duty" and served the Nazi regime may have briefly lost their jobs in 1945 but the majority were smoothly reintegrated by getting party memberships in the ÖVP and SPÖ..$^{14}$ Many of those who had supported the authoritarian Dollfuss and Schuschnigg and the totalitarian Hitler regimes did not pay a price after $1945 .^{15}$

Statism, the "long shadow of the Austrian state" so deeply-rooted in Austrian political consciousness, prevailed after World War II. So did the political symbolism with the revival of the prewar constitution, coat-of-arms and flag (only a new hymn was written) ${ }^{16}$ Renner ruled his Cabinet like a mini-Metternich. He dominated decision-making in the "Staatsrat" with the principal party leaders. His full Cabinet then discussed these decisions but ultimately had to endorse them. $\mathrm{He}$ single-handedly nipped any basic constitutional debate in the bud by pressuring his Cabinet to reinstitute the Constitution of 1920, which was amended in 1929. Naturally, by perceiving the enemy in the Austro-Fascist regime rather than in National Socialism, which he had endorsed in 1938, Renner did not want to return to the authoritarian constitution of 1934. But neither did he desire to unleash a lengthy constitutional debate. Renner found all the support he needed in his coalition, when the Communists demanded a new constitution that would be "more democratic" like those in the "people's democracies" established in Eastern Europe. Obviously, the Austrian model for democratic government would not the "people's democracies." The Communists and their Soviet patrons criticized the Austrian government as late as 1950 for their failure to rewrite the constitution.

The American planners actually had envisioned a similar process that had been used in southern reconstruction after the American Civil War (1861-65). After the setting up of an interim provisional government they wanted the election of a 
constituent assembly that could (presumably draft and) promulgate a new constitution. While the process of the reconstitution of the new Austria was going on, the occupation authorities could rely on the provisions of the 1920 Constitution, amended in 1929. The provisional government emerging in Vienna in the late days of April 1945, of course, was not to the liking of the Anglo-American powers. Renner most likely had no inkling of such American plans. Relying on his practical experience of 1919, the shrewd opportunist Renner followed his healthy instincts as nation builder and nipped, in the bud, any lengthy constitutional debate, which might revive the old party strife by reinstituting the 1920/1929 constitution. ${ }^{17}$

Renner operated on the age-old Austrian political culture of enlightened authoritarianism, where patronizing small political elites made the crucial decisions in the style of Emperor Joseph in the best interest of the people. ${ }^{18}$ Such "Josephinism" did not need public opinion or allow for contentious political debates. ${ }^{19}$ The patronizing style of Austria's political elites prevailed in the grand coalition long after Renner. Take Austria's secret rearmament in the early 1950s as an example. The Communist strike of October 1950 (frequently exaggerated to have been a "putsch attempt") precipitated the building of the nucleus of an Austrian army. It was driven and financed by the Americans in close cooperation with some Austrian military planners and the top Austrian leadership (Figl, Gruber, Schärf and Helmer). Given the high level of secrecy, parliament was not consulted, let alone the public informed. But then, much of Austria's postwar legislation was generated in a similar fashion from the "top down." Draft bills were written by senior experts in the ministerial bureaucracy, then passed by the coalition leadership in Cabinet sessions, before they were rubberstamped by parliament to become laws. The public was denied any input - it had to swallow and live with the results. ${ }^{20}$

The great fear in the Second Republic was a return to the confrontational politics of the First Republic. The sea change in the Second Republic amounted to creation of political consensus across the principal political camps. This amounted to a reinvention of Austrian political culture. This basic acceptance of political cooperation and the spirit of bipartisan consensus across the jagged old ideological divides, born from the trauma of prewar party stride between the camps, marked the principal difference to the First Republic. ${ }^{21}$ While the political leaders of the First Republic such as Otto Bauer and Ignaz Seipel had been intellectual heavyweights beyond the narrow Austrian confines, the leadership of the Second Republic (not counting Renner and Bruno Kreisky), with their narrow-minded pragmatism, was a better fit for small Austria. ${ }^{22}$

Proporz - the unique postwar Austrian system of massive patronage - became the principal tool to build this cherished consensus (its pendant in the arena of political economy was the Austrocorporatist "Sozialpartnerschaft"). The Ameri- 
can planners had anticipated the most important problem of future Austrian political tranquility: "success of democracy in Austria will depend on an adjustment of the political differences between the two sections of the population formerly organized in the Christian Social and Social Democratic parties" (emphasis added). ${ }^{23}$ To guarantee postwar political stability the Western occupation powers forced these two principal camps dominating Austrian political life to cooperating throughout the occupation period. At the slightest hint of tensions in the fragile coalition (and they were frequent), the Americans and British called on party leaders and reminded them that the grand coalition was the best recipe for political stability in Austria, as well as maintaining the anti-communist consensus (the enemy image of postwar anti-communism glued the ÖVP and SPÖ together and amounted to a quasi-constitutional political force ${ }^{24}$ ). In 1946 the British Labor government even considered using the Pope as mediator to remind the People's Party not to threaten the coalition with their constant backbiting and bickering. One American observer noted that only a shared "distaste for communism" held the coalition together, otherwise they remained "steadfast in their disagreements on most other issues." Indeed, during the emerging Cold War East-West conflict, rabid anti-communism ("red fascism") became the new postwar ideology uniting the two dominant Austrian political camps and replacing their old ideological baggage that had disunited them so profoundly before the war. ${ }^{25}$ Like in West Germany later, "Entideologisierung" was the basic prerequisite for political comity. Both camps had to abandon much of the heritage of their traditional Catholic and Marxist ideologies respectively.

"Lustrace" Austrian-style was agreeing on taboo zones ("Tabuisierung") about Austria's homegrown Fascist and National Socialist past (1933-1945). The conspiracy of silence about Austria's recent past was the other crucial precondition for fostering cooperation in the grand coalition governments after 1945. The Socialists had to forget that many in the People's Party had served the Austro-Fascist regime, which in 1934 had thrown them into jail and drove them into exile. The People's Party had to suppress the anticlerical tradition in the Socialist Party. After the Anschluss many Socialists (including Renner) had allied themselves with the NS regime and helped deport the likes of Figl and Hurdes into concentration camps. Under the tutelage of the Western occupation powers an implicit agreement was reached that the new enemy was neither the prewar ideological foe nor the Fascist/Nazi threat from the past, but the "red peril" on Austria's (and West Germany's) borders.

Constructing and agreeing on a new common master narrative of history was mandatory for the strange bedfellows in the Austrian coalition to stay in bed together. The postwar consensus was built on this "coalition history." 26 It was built on taboos and repressed memory of the Austrofascist and Nazi pasts and the powerful myth of Austria as first victim of Nazism. With their ambiguous Moscow 
Declaration of 1943 the occupation powers provided the basic tool for constructing this postwar myth. Anglo-American planning had been based on the premise now called a "half-truth" by historians - of Austria as a "victim of Nazi aggression rather than integral part of Germany." Peter Pulzer is correct in averring that such "reconciliation meant a conspiracy of silence about the past." By 1955 the People's Party and the Socialists had made coalition governments and the rich patronage of Proporz the mainstays of Austria's new political culture of consensus politics. In spite of habitual disagreement and tensions over most important political issues, the "grand coalition" survived until 1966 and revived again during the past fourteen years (1986-2000). Peter Pulzer's judgement is again on the mark when he charges that the coalition practiced "suffocating avoidance of controversy." It also stifled "the types of conflicts that are inherent in a modern, mature society" and the lifeblood of settled democracies. ${ }^{27}$

\section{Preempting Reform: \\ The Exclusion of Emigrés and the Resistance from Political Reconstruction}

One of the prime lessons from twentieth century totalitarianism has been that resistance fighters and dissidents have to be considered as the conscience of their nations. Active defiance of totalitarian repression takes courage and deserves the highest respect. The Scholl siblings and Martin Niemöller (or Franz Jägerstätter in the Ostmark) did not bring down Nazism. But their noble deeds helped postwar Germany appreciate the survival of a tiny core of decent humanity - civilization had not entirely been uprooted under Hitler. Similarly, Andrei Shakarov, Vaclav Havel and Lech Walesa did not bring down communism but helped preserve a sense of decent humanity under the long dark night of Communist oppression. The Czech people showed extraordinary gratitude towards Havel for the courage of his convictions by honoring him with the highest office in their land. No such Havels as the postwar Austrian George Washington!

It became both hallmark and yardstick of the character of postwar political regimes in Germany and Austria whether the postwar political elites dared include those who had actively resisted National Socialism and invite the emigrants from Nazi oppression back. In Germany emigrés were welcomed back and resistance fighters included in the new political elites. Both contributed to rejunvenating the democratic climate and actively confronting the past. In Austria emigrants were generally not invited back; the new regime also failed to include resistance fighters. Why were the Austrians so ungenerous towards those who single-handedly preserved the continuity of the Austrian nation abroad or in the underground at home under most difficult circumstances? 
With his two volumes on the "Vertriebene Vernunft," Friedrich Stadler has documented the massive exodus of artistic talent and intellect from Austria in 1938 and in previous years. ${ }^{28}$ In the course of World War II some 130,000 Austrians ended up in exile in 90 different countries around the globe. It is rare in the annals of history for a nation to suffer such a massive self-inflicted brain drain. The personal serendipitous journeys towards physical survival and safety of those expelled were harrowing, as Egon Schwarz has recently reminded us. ${ }^{29}$ Admission and assimilation to new cultures was always painful and difficult. Given the intellect and education backgrounds of a Paul Lazarsfeld, Marie Jahoda, Ernst Badian, Raul Hilberg, Karl Popper, Friedrich von Hayek, Ludwig von Mises, Gottfried Haberler, Victor Weisskopf, Billy Wilder, Hilde Spiel, Stefan Zweig, Oskar Kokoschka, Joseph Roth, Henry Grunwald and the endless list of gifted Viennese Jews who were often brutally expelled after the Anschluss, they would go on to brilliant careers in academia, science and the arts in exile and soon fill the Who's Who of Anglo-American arts and letters. Their gain was Austria's loss. They helped make American universities the intellectual hub of the world. Their absence cast Austrian universities into a long postwar twilight of provinciality and mediocrity. ${ }^{30}$

Ironically, these cosmopolitan exiles were also the most profound Austrian patriots. More than the numerous Nazi fellow travelers and Mitläufer, who sat the war out in the Ostmark, these emigrés kept the idea of Austria alive. They formed the "Free Austrian Movement" in London and defied Hitler's attempt to erase the idea of Austria. As Edward Timms has demonstrated, London became Austria's intellectual and cultural capital during the war with regular lectures, art shows and exhibits being organized by the gifted Austrian exile community. While the exiled Socialist and Christian Social politicians carried on with their interminable prewar ideological feuds in Prague, Paris, London and New York, the intellectual and artistic emigré community preserved and breathed life into the idea of Austria. ${ }^{31}$

Uninspiring university professors in the 1940s and 1950s and 1960s, who often had served the Nazi regime, created dull and lazy minds who failed to absorb new ideas from abroad and favored tradition and restoration and failed to question authority. Only in the 1960s did a younger generation, born during or soon after the war, start to question such dull-witted authority, when their protests forced the resignation of the unreconstructed Nazi and outspokenly racist anti-Semite with the unlikely German name of Taras Borodajkewicz from the Economics University in Vienna. ${ }^{32}$ An intellectually unquestioning climate in the universities, of course, provided the ambiance to cement the postwar consensus that petrified the coalition for so long and made reform and democratic renewal so difficult. Who could question that the political apathy of the wartime/postwar generation was related to this? Austria was too poor for an American-style "GI-Bill of Rights" to educate and democratize in the marketplace of ideas the veterans that had been 
politically socialized in the Hitler Youth and then "did their duty" in the deadly and aggressive German Wehrmacht. The failure to bring back the "best and the brightest" expelled in 1938 amounted to the raising of an iron curtain vis-à-vis democratic renewal and lively intellectual discourse; the fostering of a vibrant civil society was nipped in the bud early. Here too patronizing Josephinian restoration generally prevailed over reform.

Most of these talented emigrés were not invited back because they were Jews. Most refugees that had been politically active before the war had been Socialists. Anti-semitism after the war was no longer as vile and brutally open as in had been in 1938. It flowered more subtly behind the scenes. The postwar Socialist Party set out to liberate itself of the brilliant Jewish leadership that had dominated the party before the war. The SPÖ consequently moved from the Austro-Marxism left to the tame middle of the political spectrum. The postwar leaders of the SPÖ came from the prewar moderate right wing like Renner, or were younger party hacks such as Schärf and Oskar Helmer. People like Helmer and Heinrich Schneidmandl from rural Lower Austria were intimidated by the sharp intellect of the urban Viennese Jews and did not want them back. It would have threatened their ascendancy to positions of power in the party. Having sat out the war at home supposedly entitled them to enjoy the rich postwar party patronage. Their mild anti-semitism and rabid anti-communism not only helped build the coalition consensus in the "shotgun marriage" with their reluctant old ideological enemies in the ÖVP, but also endeared them to the Western occupation powers in the emerging Cold War. These new Socialists were even more pro-American than their hidebound ÖVP counterparts. ${ }^{33}$

Only few emigrés returned after 1945. Oskar Pollak came back from London to edit the Arbeiterzeitung. A small group of a younger generation of Jewish Socialists like Bruno Kreisky, Walter Wodak, and Hans Thalberg returned from exile to go into the diplomatic service; they became the leading impresarios of formulating Austrian foreign policy in the 1960's and 1970's. Kreisky is the best example to demonstrate how valuable the return and reintegration of talented Jewish Socialist refugees was for the SPÖ. He put his dominant imprint on the Socialist Party and Austrian politics during a time of belated democratic renewal in the 1970s and single-handedly kept the Socialists in power for an entire generation. Otto Leichter's attempt to come back and assume the intellectual leadership of the SPÖ as the postwar Otto Bauer failed. Schärf apparently would have welcomed the return of theoreticians like Benedikt Kautsky and Adolf Sturmthal, but his party was not exited about the prospect of reintegrating such serious intellectuals. $^{34}$

Hilde Spiel returned for a few weeks in the spring of 1946 under the auspices of the British Army and left with a devastating account of the intellectual climate prevailing in Vienna: 
Here everything is delightful apart from the attitude of the Viennese, who are either Nazis (whose sting has admittedly been drawn), or charming, politically absurd members of the Volkspartei, or prosaic bourgeois Social Democrats, or doctrinaire Communists, or charming but absurd Communists. That is roughly the extent of it. They are either corrupt or exhausted or politically obtuse or fanatical, but one thing does speak in their favour: their great love of art ... I am convinced that the only chance for the Austrians lies in their enormous talent for all art forms, their exceptionally good taste and their artistic sensitivity. If they learn to restrain themselves and to leave politics to others, they will have a future in Europe.

The culture that reawakened was very traditional and the politics hidebound. In his fine essay on Spiel, Timms concludes that "those who did return found little scope for realizing their dream of a 'Free Austria' - radical socialist democracy in which they would themselves have been welcomed back to provide a new style of intellectual leadership." 35

While the exiles, who had personally experienced vibrant but confrontational democracies at work in England and the U.S., were not welcomed back, the fellow traveling Nazis were on the rise again and were quickly reintegrated into Austrian life. The Mitläufer did not want to be reminded by the exiles, who had cultivated the idea of the Austrian nation during the war, that they had abandoned not only their conscience but also bet on the wrong horse and lost. The fellow travelers felt comfortable living in a hidebound Austria now almost without Jews. ${ }^{36}$

The restored Austria also unceremoniously rejected the participation of resistance fighters in positions of political leadership in its postwar political reconstruction. Austria's resistance movement during the war operated under extraordinary difficult circumstances and never took off. The majority of dedicated and courageous resistance fighters were Catholics and Communists. Most of them went to concentration camps or the execution blocks early in the war. Laissez-faire Austrians seem to be better followers than resisters. In a country where regimes have changed frequently in the twentieth century switching party allegiance becomes a way of survival for the hangers-on. It had happened in 1938 and would happen again in 1945. This also means that political convictions cannot be running very deep, let alone fighting for one's persuasions. Most Austrians ("Ostmärkers") were lethargic during the war and not prepared "to sacrifice their lives in a somewhat forlorn cause," reported the OSS. The typical Viennese was an indifferent grumbler ("Raunzer"). The OSS reported a representative Viennese as noting: "I do not care how the war ends. All I want is to be able to get my motor car back." When the war ended they joined their old political camps again - some even took a secret Communist Party membership as an insurance policy for worse to come. ${ }^{37}$ 
Austrians after the war did not want to be reminded by resistance fighters that most of them had failed in providing aid to bring down the Nazi regime. By not including them in leadership roles they could not agitate as the conscience of the nation and possibly even demand reparations for the suffering of the true victims of the Nazi regime. Most Austrians preferred constructing the myth that they all had been victims of the war and therefore deserved reintegration into society and possibly even reparations or welfare (eg. crippled veterans) rather than grant Jews, euthanasia victims and resistance fighters a special status of victimhood.

The only resistance fighter from the " $0-5$ " organization to make it into the Provisional Renner Government as an Under State Secretary in the Communist controlled Interior Ministry was the colorful maverick Raoul Bumballa. Renner presumably included him only upon communist pressure to have at least one resistance fighter in the coalition. Operating within the People's Party in the summer of 1945 Bumballa tried to form a liberal wing to make it "a new party and more democratic party with a definite middle class and international orientation." But the peasant and clerical reaction in the ÖVP feared that such a liberal wing might split the party and rejected Bumballa's attempts at democratic modernization. Oliver Rathkolb is on the mark in concluding that only "experienced party hacks with good contacts in Austria managed to launch political careers after 1945." 38 The return of these obtuse prewar party warriors effectively contained both wartime dissidents and emigrés from playing prominent political roles.

Karl Gruber was the exception to the rule. The young man from the Tyrol had somehow managed to sit the war out in Berlin. In the final weeks of the war he joined the resistance movement in the Tyrol and emerged as a leader and province's first postwar provisional governor, in part due also to his knowledge of English and his maverick daredevil character. Once the Western powers had established their presence in Vienna by September 1945, Renner called a conference with representatives from all the states ("Länderkonferenz") to broaden his Provisional Government and make it acceptable to the West. The 37-year old Gruber received the Foreign Ministry probably more for reasons of including some politicians from the Western provinces than to have a resistance fighter in the government. His diplomacy was also expected to accomplish the return of the South Tyrol for Austria. Gruber's record as resistance fighter came in very handily in persuading the world that Austria had been a nation of victims during World War II. Incidentally, the diplomatic leadership returning to the Foreign Office in April/ May 1945 already had been serving in the Dollfuss and Schuschnigg Foreign Ministry and was either fired in 1938, gone into exile (some into "inner" exile), or were shipped to concentration camps. The profile of such opposition to the Nazi regime, along with a younger generation of Socialist exiles who returned from England, France and Sweden made the Foreign Ministry bureaucracy an unusual exception in its discontinuity with the Nationals Socialist regime. ${ }^{39}$ 
The unmistakable trend in postwar Austrian politics, then, was not to call upon the expelled Jews or the wartime resistance fighters as the noble conscience to reconstitute the nation in democratic renewal; instead the entrenched old party hacks began to practice consensus, Proporz and Sozialpartnerschaft.

\section{Reemergence of the Fellow Travelers and Political Apathy: Denazification and Public Opinion}

The reestablishment of a viable Austrian polity after the war required the purge of the Fascist/Nazi mindset just like viable democracy in the post-Communist regimes in Eastern Europe called for the purge of the totalitarian mindset through investigations into the "Stasi-regimes" and/or "lustrace" measures. Central European transitions after 1945 and 1989 have demonstrated that such radical breaks with the past are fraught with difficulties. The huge segments of population that had aligned themselves with the totalitarian regimes made wholesale purges impossible and called for amnesties as well as forgiving and forgetting.

Denazification can be seen as a from-the-top-down bureaucratic approach to purge Nazi ideology from the body politic and reeducate a mindset that had been steeped in totalitarian doctrine, in the case of Austria for twelve years (1933-45). It can also be perceived as a great chance for democratic renewal. The half-hearted attempt to purge the Nazi-mentalité constitutes a missed opportunity for democratic renewal and building a framework for civil society to prosper (in the former Soviet satellites the concept of civil society was a much stronger model for nation building after 1989 than it had been in postwar Austria). After 1945 democracy in postwar Austria was implanted from above in the usual paternalistic Austrian fashion. It was accompanied on the one hand by a mild tutelage from the Western occupation powers and on the other hand constant charges from the Soviet occupiers of both failed denazification and "democratization". It did not provide for grass roots democracy to sprout on the local level and grow into genuine selfgovernment. ${ }^{40}$

The Ostmark had some 537,000 registered party members (about 12 percent of the population). It had produced the likes of Adolf Eichmann, Odilo Globocnik and Friedrich Rainer and other infamous Nazi butchers and bureaucrats, who had contributed inordinately to the implementation of the Holocaust and Nazi atrocities all over occupied Europe. Austrians served in the police and SS units, which implemented the early stages of the final solution in Eastern and Southern Europe. Moreover, almost 1.3 million Austrians served in the Wehrmacht, ${ }^{41}$ which more recently has been singled out by historians as having played a prominent role in the implementation of the Holocaust. What to do with this mass of more or 
less implicated "Nazis," fellow travelers and "doing-their duty" fellow travelers ("Pflichthengste")?

In order to build a new spirit of political comity and consensus between the camps in postwar Austria, not all NS-party members could be sent to jail. Until 1949 they suffered disenfranchisement and political (not social!) isolation. Very soon after Austria's liberation and until the end of 1945 two denazification regimes emerged: an Allied one and an Austrian one. The four occupation powers initiated their own denazification regimes in the course of 1945, based on their more or less complete planning efforts during the war to eradicate Nazism and punish the implicated Nazis. The Americans came to Austria intent on severe denazification. Initially they even planned to go after the Austro-fascists. They quickly realized that this would have rendered the People Party non-viable. When they instituted their elaborate questionnaires to be filled out by former Nazis, their efforts soon bogged down in bureaucratic inertia. The British half-heartedly followed the American model but were more interested in building democracy than alienating the huge stock of Nazi fellow travelers along with their families. The French had learned before they came to Austria that wholesale purges produced chaotic situations and entered Austria more skeptical about the chances of denazification. The Soviets wanted to punish the worst-case offenders quickly and attract the "little Nazis" into their ranks by exercising forgiveness. When the Austrians elected their own government in November 1945, the Allies handed their bogged-down and ambivalent denazification efforts over to the Austrians. Starting in 1946 they merely supervised Austrian denazification. It quickly bogged down in the Cold War when the West considered an anti-Communist Austria a higher priority than a thorough Nazi purge. ${ }^{43}$

Vigorous Austrian denazification efforts had begun right after the war but quickly eased with the alleviating of Allied pressure for a thorough purge. In its first few weeks in office, the very productive Provisional Renner Government debated and passed two tough denazification laws - one criminalizing all Nazi organizations (Verbotsgesetz), the other defining and beginning to persecute the worst war criminals (Kriegsverbrechergesetz). During these early Cabinet discussions the very peculiar Austrian species of a "good Nazi" emerged - the perennial fellow traveler ("Mitläufer"), who joins each and every political movement coming to power as a survival strategy. The argument went that one could not possibly exercise tough punishment on the Mitläufer, since they had never been very serious about their Nazi party affiliation. They had passively joined to keep their jobs, or only run with the Nazi crowd under pressure. They were supposed to be screened, atone for their errors and permitted to redeem themselves. "To outlaw them and make pariahs out of them," argued the Communist Minister of Education Ernst Fischer who had just returned from Moscow, "would not only be unwise but also unjust."44

One wonders how all those people, who had welcomed the German Army en- 
thusiastically on March 12, 1938, managed to return to the woodwork? From day one of the Second Republic, the political camps competed for the vote of these fellow-traveling "good Nazis." The Communists right away after liberation, the People Party close second, and the Socialists last. When in 1948 the 480,000 "good Nazis" were amnestied, the competition for their votes became fierce and ended in the creation of a "fourth party." The new "League of Independents" captured many of their votes but so did the SPÖ and ÖVP. Austrian denazification efforts were most vigorous as long as the occupation powers kept the pressure on in 1946/47. With the Cold War came the great amnesties of 1948. Denazification increasingly became a political football in the growing propaganda battles of the Cold War. Austria did punish some 40,000 Nazis ("Belastete") through disfranchisement and loss of political rights, exclusion from the workplace and loss of jobs, fines and even jail sentences and internment camps. Fourty-two of the worst case offenders were executed. As soon as the occupation powers left, most of the Nazis still in jail were amnestied. By 1957 the Austrian effort had petered out. There were few riveting trials of Nazis in Austria like the Eichman trial in Jerusalem or the Auschwitz trials in West Germany, which also turned into effective contemporary history and civics lessons about the depravity of the Nazi regime for an entire nation. The lack of Nazi trials in Austria in the 1960s, in fact, aided the Austrians in their skillful art of forgetting and historical amnesia. ${ }^{45}$

Most Austrian Mitläufer soon came to see themselves as "victims of denazification" and griped about the impertinence of being branded as "Nazis." In another one of those peculiar postwar Austrian inversions of reality, "the harshness of deNazification laws was termed 'undemocratic' [emphasis added]." 46 The Mitläufer and the returning soldiers argued that they had only "done their duty" and did not feel responsible for Hitlerite war crimes. 71 percent of Austrians felt that "the Austrian people do not share in the guilt for World War II and only 15 percent thought Austrians were partly to blame." The Austrian-born American diplomat Martin F. Herz correctly concluded from this polling evidence: "It stands to reason that the emphasis on Austria's separateness from Germany results in corresponding feeling of guiltlessness [emphasis added]." ${ }^{\prime 47}$ It seems like a major moral failure aided and abetted by the church that in deeply Catholic Austria no record of remorse ever surfaced over Austrians' major contributions to the implementation of the Holocaust and brutal and destructive Hitlerite expansionism, occupation and exploitation. Instead, a strange inversion of "victims" emerged in postwar Austria, where Jews and resistance fighters had no special claim to victim status. By 1950 all of Austria perceived of itself as a "nation of victims." The veteran organizations got busy commemorating their "Kriegsopfer." Denazification and exclusion from both politics and the civic arena before 1949 bred political apathy. So did the continued foreign occupation. The Austrian government was more serious in instilling the idea of a non-German "Austrian nation" than in 
purging the Nazi mindset and reeducating the population in a liberal democratic value system. With the coming of the Cold War, the Western occupation powers withdrew their pressure to cleanse the body politic from the mental baggage of Nazi racism and aggression. Until the 1980s forgetting became the Austrian trajectory of postwar remembrance. ${ }^{48}$

The high bureaucracy led the charge. Austrian schools concentrated on teaching the new doctrines of "Austrian identity" constructed in the Education Ministry after 1945 by bureaucrats, who had faithfully served the prewar authoritarian regimes. They evoked Austria's great historical pre-World War I past and stressed its separateness from Germany. The World War II war crimes had been imported from Germany. Austrians had had no part in them. The reactionary Ministry of Education officials missed the opportunity to instill liberal democratic values. The Foreign Ministry officials set out on their mission to persuade the world of the basic postwar Austrian doctrines: Austria's victim's status and sterling resistance record during the war. Official government publications such as the RedWhite-Red book spread these historical half-truths. These doctrines also had to be popularized in the domestic arena. State sponsored propaganda exhibitions such Niemals Vergessen did the trick. Hundreds of thousands of Austrians saw this show in Vienna in the fall of $1946 .{ }^{49}$

The school curricula pushed this indoctrination via the school curricula. Nazi atrocities were generally mentioned only in tandem with Allied atrocities like the bombing of Dresden. In this peculiar moral equivalency the Hiroshima bombing was on the same level as the Nazi Holocaust. Once the "final solution" started entering the schoolbooks in the 1960s and 1970s, the specific role of Austrians went unnoticed. Loyalty to the new Austrian state (i.e. reinforcing the "long shadow of the state") had a much higher priority than a liberal democratic value system and the ideal of autonomous political responsibility. The Josephinian ideal of Austrian citizenship prevailed - to be loyal subjects to the authority of an all enlightened state. Simple patriotism prevailed over a democratic and anti-fascist agenda. ${ }^{50}$

Parallel to this curricular policy of instilling the sense of separate Austrian nationhood in the youth, the hidebound Ministry of Education pushed a "postfascist" (R. Fleck) agenda rather than a clean sweep with the past. Writers like Heimito von Doderer were favored and coddled with state prizes. Von Doderer had thrown in his lot with the Nazi regime and after the war became a propagandist of the Austrian idea by creating the Habsburg myth of Austria's great historical past. No Thomas Manns appeared on the scene. Mann returned to Germany as the great representative of "the integrity of a better Germany in exile" (A. Bushell). Famous Austrian exile writers like Stefan Zweig and Joseph Roth had committed suicide in exile or drank themselves to death. Young writers who had been expelled like Hilde Spiel returned only with the occupation forces as observers of 
postwar Austria. The University of Vienna refused to give Hermann Broch, who had fled Nazi Germany, an honorary doctorate. Like ordinary Austrians, the obsequious writers survived the regime changes. Those who acted as conscience to their nation and took the hard road to exile lost their homeland permanently. ${ }^{51}$

A similar restoration of the prewar aesthetic occurred in the Austrian art and literary scene. In postwar Austria the Nazi idea of "degenerate art" died a slow death. Young artists had a hard time getting access to the new aesthetic of radical modernism and abstract expressionism unless they went to Paris or New York, which few of them could afford. In the Academies of Art the professors who had taught during the war kept their jobs and continued with their hidebound pathetical aesthetic after the war. Radical abstractionism came to Austria late. The highly experimental "Viennese action group" of the Sixties was a reaction against this postwar restoration, just like Gernot Wolfsgruber's and Franz Innerhofer's attacks on Austria's feudal society and the crypto-serfdom of its people were responses to the continuity in Austrian literature after the war. ${ }^{52}$

The cultural milieu in Austria after 1945 was as distinctively anti-modernist as it had been before the war. As Dieter Binder has persuasively argued, Austrian cultural elites continued to see creative individualism as a destructive force threatening the imagined national unity. The same generation was in charge that dominated cultural debates before and during the war and rejected experiments. In the prevailing Cold War mindset intellectuals such as Friedrich Torberg and Hans Weigel practised Austrian-style anti-communist McCarthyism. The postwar return of hidebound backward-looking pride in everything "Heimat" was only challenged by a new generation in the $1960 \mathrm{~s}^{53}$

The survival of this postfascist mentalité produced widespread political apathy. It resulted in both distance and ambiguity vis-a-vis liberal democratic values as the first public opinion surveys demonstrated. The American occupiers brought their obsession with public opinion polling to postwar Austria. From 1946 onwards they regularly polled the Austrian population about the idea whether "National Socialism was a bad idea, or a good idea badly executed?" Between a third and half of the population consistently answered that it "was a good idea badly executed." When polled about their favorite form of government, only about 40 percent favored democracy, 24 percent a Socialist Republic, still 16 percent monarchy and only 3 percent outright dictatorship. 46 percent of the young Austrians in their twenties favored democracy, but only some 31 percent of their elders over 60. Austria's postfascist mindest was coupled with rabid anti-communism. This can be gathered from 1948 polls where in Vienna 36 percent preferred National Socialism, while 6 percent preferred Communism (in Salzburg 43 percent and 3 percent respectively). About 50 percent preferred neither and can be considered democrats. Oliver Rathkolb is correct in concluding that democracy had not yet 
taken firm roots in Austria and the authoritarian fascist potential was still strong in postwar Austria. ${ }^{54}$

In 1951 the State Department sent the well-known political scientist as a consultant to Austria to assess the country's state of mind. After his many interviews with Austria's political elites Morgenthau wrote a long report about Austrian political culture. He observed the consensus democracy emanating from the "shot gun marriage" of the ÖVP-SPÖ coalition; he also observed the shallow roots of democratic institutions in political and economic life. He saw deep political apathy in the population and disinterest in politics among the youth. In another report a pupil from the 1950s is reported as saying: "I am not concerned with the political situation, or only as much as it is befitting an Austrian citizen." ${ }_{55}$

Given this long postwar history of official soft-pedaling of National Socialism it should not come as a surprise in the late 1980's that the Austrians generally harbored much more positive views of National Socialism than the West Germans with their much more strict postwar reeducation policies did. While 16 percent of the Austrian population thought that National Socialism featured "only bad sides," almost twice as many (29 percent) of the West Germans thought so (43 percent of the Austrians felt National Socialism had "bad and good sides," while 35 percent of the West Germans agreed with this proposition). Small wonder that the populist Jörg Haider's positive references to National Socialism produced so much political support rather than profound disgust. ${ }^{56}$

This postfascist mindest runs concurrent with the low prestige of democratic government in postwar Austria. Given the general political apathy dating back to the Nazi period, as well as the above mentioned quasi-authoritarian approach to politics by a patronizing and small political elite, the average Austrian citizen took little interest in politics and less in the rejuvenation of democracy. Austrians regarded democracy as "the antithesis of repression and dictatorship." Austrians desired democracy "as a political atmosphere," argued Martin F. Herz, but distrusted it "as a method for getting things done." Parliament as an institution had little prestige because "it seems incapable of reaching quick decisions." The grand coalition agenda of uncompromising consensus democracy had proffered a view that saw "discord between political parties not as evidence of the of the vitality of Austrian democracy, but as a dangerous deviation from it." In 1945 and thereafter Austrians were in general very tired of political parties. Political campaigning reminded them of Nazi party propaganda. Austrians associated party competition with the strife and struggle of the prewar party system, the give and take of contentious democratic discourse with a general disturbance of the political consensus. Austrians were ignorant of the fact, argued Herz, "that a democracy without active, virile parties is doomed." ${ }^{57}$ 


\section{Conclusion}

The Vienna-born American diplomat Martin F. Herz was a keen observer of postwar Austrian politics and political culture. He interviewed most of the Austrian political leaders after he entered Vienna late in July 1945. He recognized early on the deep-seated suspicion between the People's Party and the Socialists, papered over by superficial consensus politics and desire for unity after the trauma of prewar party strife between the camps. He recognized that Austrian ignorance about the essence of democracy was deeply rooted in the contentiousness of constant prewar clashes between political opinions and parties. Herz's subtle skills as political observer also gathered the deep roots of mutual historical recriminations in both political camps. The Socialists gave the purging of "Heimwehr-Fascism" in the People Party higher priority than the eradication of Nazism, while the People's Party constantly dwelt on the Socialists' unpatriotic pro-German Anschluss orientation before the war. ${ }^{58}$

Were there any alternative paths available in 1945? As early as October 1945 Herz suggested one. He advised the Allies to interfere in the domestic Austrian battle over the country's past and the future of its democracy by truthfully addressing their parties' historical mistakes in the prewar period. "To avoid the fatal handicap of Austrian democracy," Herz averred, the Socialists should be forced to openly renounce the Anschluss idea as a mistake and the People Party should "be made to dissociate itself clearly and publicly from the anti-democratic heritage of the Christian Social party" (Herz's emphasis). He also suggested that the Allied Council should issue a historical review of the prewar period in which "the pernicious elements of the totalitarian state is clearly exposed." When the Allies were ready to end their occupation, Herz suggested, they should leave behind a solemnly worded "Charter for Austrian Democracy." Therein a review of Austrian democracy should be attempted and the two principal camps be admonished not to resuscitate their past ideological struggles. This authoritative Charter could be a quasi "Declaration of Austrian Independence" - a postwar Austrian magna carta serving as the "basis for study in Austrian schools and for public display for a long period of time to come." Herz added: "It might, equally fittingly, contain brief discussions of the rights of man, of civil liberties, the treatment of minorities, and the benefits of the parliamentary system." 59

The trajectory of postwar Austrian democracy might have been quite different had the occupation powers interfered more strongly after the war to remind the Austrians to face their historical failures squarely in order to start mastering their own past. Such an Austrian "bill of rights" might also have reeducated the Austrians more deeply about the nature of democratic government, human rights and civil society. But the occupation powers did not do so and thus permitted the historical untruths or half-truths expressed in Renner's Declaration of Independ- 
ence from April 27, 1945, and subsequent official pronouncements such as the Red-White-Red book to stand. Austria, after all, was a liberated country where the Allies generally allowed Austrians to take matters of domestic governance into their own hands. They did not control Austria like defeated Germany, were Allied control of domestic politics was total until 1947/48.

This allowed Austria to revive democratic government in their age-old way of paternalistic enlightened authoritarianism. No enlightened electorate was needed and one actively participating in governance not desired. The complex historical truth was papered over with the myth of Austrian victimhood during World War II, possibly a necessary historical fiction designed to build a truce between the two camps and consign their ideological antagonism to the past. The Western powers went along with and supported this historical fiction, both to build much needed political stability for the economic reconstruction of the country and keep the strongly anti-communist Austria in the Western fold during the Cold War struggle against the Soviet Union.

Ultimately, the massive postwar American economic aid proved to be the strongest nostrum for Austria's postwar political reconstruction. After 1945 Austrian democracy survived on a steady diet of U.S. Army and UNRRA food aid and the Marshall Plan. The spectacular success of the reconstruction of the Austrian economy in the 1950s allowed the grand coalition to paper over their deep-seated mutual suspicions and firmly rooted ideological disagreements. Economic revival and growing prosperity fostered cooperation across the camps and reinforced consensus politics. The prewar myth of Austria's non-viable economy was proven to be a myth only. The Marshall Plan helped give Austrians their cars back and injected broad prosperity into the country. This postwar economic prosperity - along with the Western pressure to work out their mutual hostility - gave the grand coalition sufficient time to stay together, reluctantly respect each other, and gradually begin the strengthening of formal democratic governance in the next generation. ${ }^{60}$

It seems that the Austrian population instinctively recognized this crucial nexus between economic prosperity and political stability. Austrians were polled in 1995 on what they considered the most crucial factors for Austria's reconstruction in 1945. 37 percent answered the reconstruction of the economy, 33 percent rebuilding of democracy; again it does not come as a surprise that a meager 6 percent considered denazification as the top priority. ${ }^{61}$

"Inner democracy" along the lines of a "liberal consensus" began to sprout in Western Germany in the 1960s. Authoritarian patterns of behavior, long considered national traditions and deeply rooted in German society receded slowly. In his anatomy of postwar Austrian democracy the German historian Anselm DoeringManteuffel has shown how the long shadow of the state in Germany began to pale over a long period of time. The old patterns of a political culture that priced loy- 
alty to the state above all else were replaced in the new West Germany by a new political culture of "discussion, participation, and reconciliation." The German baby boomers helped unleash this new political culture by forcing an active discourse about the crimes of Nazi Germany and the German guilt emanating from the Holocaust upon their fathers' generation. The new Socialist German Chancellor Willi Brandt posited the new paradigm: "We will dare more democracy." Democracy became the cornerstone of both state and society in West Germany. ${ }^{62}$ It was much aided by strict American reeducation policies that helped unleash the astounding Westernization and Americanization of West Germany. This also included the planting of deep roots of liberal democracy - what Jürgen Habermas in the much different context of the 1980s "Historikerstreit" has called a new West German "constitutional patriotism."

The hypothesis here is that in the Austrian transition such "inner democracy" (Western-style liberal democracy) has been different from West Germany's and came about considerably later. In Austria the Socialist government of Bruno Kreisky began to "dare more democracy" in the 1970s. Kreisky presumably followed the experiment in democratic renewal by his friend Willi Brandt closely. The Austrian 1968'ers (among them Kreisky's own son Peter), led by artists and writers, demanded more democratic transparency in the political institutions; they also called for the long overdue confrontation with the past. Yet for pragmatic political reasons, Kreisky did not dare to question the prevailing political consensus of the "victim's myth." In Austria the debate about the country's World War II taboos did not break open until the 1980s.

"The infusion of democracy" in the universities through Kreisky's reform movements did open up a new spirit of discourse about the past the only came to fruition in the 1980s. The myth of Austria's World War II past were questioned in a wholesale fashion. The old "coalition history" was exposed as a tissue of halftruths and myths that had long ago ceased to serve its purpose of building postwar consensus. The "Waldheim debate" of 1986, as well as pressure from abroad, helped speed up the process of "mastering the past." But confronting the World War II past had started earlier in the intellectual community. ${ }^{63}$

When he had to confront it in the Zwentendorf plebiscite, Kreisky did not like the outcome of the participatory democracy he had unleashed. The close result of this plebiscite forced him to stop a finished and very expensive nuclear power plant from going on line. Such successful civic action encouraged an incipient and rapidly growing environmental movement in Austria to protest government plans to build a Danube river hydroelectric power plant. Success in that highly confrontational civic campaign made "citizens movements," especially in the environmental arena, more commonplace. In the mid-1980s such participatory grass roots democracy finally had arrived in Austria and became viable and entrenched. At 
last, "inner democracy" was emerging and the long shadow of the state was beginning to recede in Austria in the 1980's as it had done in West Germany in the 1960 s. ${ }^{64}$

\section{Notes}

I would like to thank László Borhi for inviting me to the Indiana Conference, and Melanie Boulet and Peter Utgaard for their suggestions in improving this paper.

1. The Communist Ernst Fischer cited in "The views of Victor Kienböck," Herz Memorandum, Aug. 8, 1945, in: Reinhold Wangleitner, ed., Understanding Austria: The Political Reports and Analyses of Martin F. Herz Political Officer of the US Legation in Vienna, 1945-1948 (Salzburg: Neugebauer, 1984), 28.

2. For Czechoslovakia, Poland and the GDR after 1989, see Tina Rosenberg, The Haunted Land: Facing Europe's Ghosts after Communism (New York: Vintage, 1996).

3. This brief an essay obviously will not allow an exhaustive comparison.

4. Hermann-Josef Rupieper, Die Wurzeln der Westdeutschen Nachkriegsdemokratie (Opladen: Westdeutscher Verlag, 1993); Anselm Doering-Manteuffel, "Turning to the Atlantic: The Federal Republic's Ideological Reorientation, 1945-1970," in: Bulletin of the German Historical Institute 25 (Fall 1999): 3-21.

5. See also Charles Maier's reply to the Doering-Mantteuffel essay “"Mehr Sozialgeschichte Wagen': Comment on 'Turning to the Atlantic: The Federal Republic's Ideological Reorientation, 19451970," which first was delivered as the 1998 annual lecture at the German Historical Institute in Washington, D.C., ibid., 22-28.

6. Rupieper, Wurzeln, 12f; see also, Daniel E. Rogers, Politics after Hitler: The Western Allies and the German Party System (New York: New York University Press, 1995); Carolyn Eisenberg, Drawing the Line: The American Decision to Divide Germany 1944-1949 (Cambridge: Cambridge University Press, 1996).

7. Post-War Programs Committee Document 218, "The Treatment of Austria," June 8, 1944, in: Foreign Relations of the United States, 1944, vol. I: General (Washington, D.C.: Government Printing Office, 1966), 437-449 (citation 439).

8. For brief biographical sketches of all the postwar political leaders mentioned in this paragraph, see the useful prosopography by Herbert Dachs, Peter Gerlich, and Wolfgang C. Müller, eds, Die Politiker: Karrieren und Wirken Bedeutender Repräsentanten der Zweiten Republik (Vienna: Manz, 1995).

9. The text of the "declaration of independence" is reprinted in Eva-Marie Czaky, ed., Der Weg zu Freiheit und Neutralität: Dokumentation zur österreichischen Aussenpolitik 1945-1955 (Vienna, 1980), 36f.

10. Günter Bischof, Austria in the First Cold War, 1945-55: The Leverage of the Weak (London: Macmillan, 1999), 52-56.

11. This founding myth has seen an anachronistic revival by some prominent ÖVP-politicians such as Josef Riegler, Andreas Khol, Alois Mock and Josef Taus in the volume by Robert Kriechbaumer, ed., Österreichs Nationalgeschichte nach 1945: Die Spiegel der Erinnerung: Die Sicht von innen (Vienna: Böhlau 1998).

12. Based on the rich evidence of OSS reports on the Austrian situation in 1945, Oliver Rathkolb has already dismantled the myth of the "Stunde null" 15 years ago, see his Gesellschaft und Politik am Beginn der Zweiten Republik: Vetrauliche Berichte der US-Militäradministration aus Österreich 1945 in englischer Originalfassung (Vienna: Böhlau, 1985), 9-11 and passim. 
13. Eva-Marie Czaky, Franz Matscher, Gerald Stourzh, eds, Josef Schöner: Wiener Tagebuch 1944/ 1945 (Vienna: Böhlau, 1992), 198, 207, 255, 378, 395; see also Ernst Hanisch, Der Lange Schatten des Staates: Österreichische Gesellschaftsgeschichte im 20. Jahrhundert (Vienna: Ueberreuter, 1994), 395-497.

14. An interesting case study of Nazis joining the Socialist Party is Robert Hoffmann, "Aus 'Braun' mach 'Rot'," Salzburger Nachrichten, 3 May 2000.

15. Hanisch, Lange Schatten des Staates, 398; see also the case studies in Sebastian Meissl, KlausDieter Mulley, and Oliver Rahtkolb, eds, Verdrängte Schuld, verfehlte Sühne: Entnazifizierung in Österreich 1945-1955 (Vienna: Verlag für Geschichte und Politik, 1986).

16. Ernst Bruckmüller, "Die Entwicklung des Österreichbewusstseins," in Kriechbaumer, ed., Österreichische Nationalgeschichte nach 1945, 376.

17. "Future of Austria," June 8, 1944, FRUS, 1944, I, 444; on the Cabinet debates, see Protokolle des Kabinettsrates, 64-66, 75-80; most up-to-date on the constitutitonal debate, and based on new Soviet documents, is Oliver Rathkolb, "Wie homogen war Österreich 1945? Innenpolitische Optionen, in: Wolfgang Kos and Georg Rigele, eds., Inventur 45/55: Österreich im ersten Jahrzehnt der Zweiten Republik (Vienna: Sonderzahl, 1996), 167-172.

18. On Renner's authoritarian style of government, see the introduction in Gertrude Enderle-Burcel, Rudolf Jeřábek, Leopold Kammerhofer, eds., Protokolle des Kabinettsrates der Provisorischen Regierung Karl Renner 1945, vol. 1: “...im eigenen Haus Ordnung schaffen”: Protokolle des Kabinettsrates 29. April bis 10. Juli 1945 (Horn/Wien:Verlag Ferdinand Berger \& Söhne, 1995), III-XIV.

19. Günter Bischof, "Where May Meets Lazarsfeld: American Public Opinion toward Austria in the Early Cold War," in: Akira Iriye, ed., Rethinking International Relations: Ernest R. May and the Study of World Affairs (Chicago: Imprint Publications, 1998), 310; Kurt Tweraser has also averred the theme of the "Josephinian style" of government in Upper Austria, see his US-Militärregierung Oberösterreich 1945-1950, vol. 1: Sicherheitspolitische Aspekte der amerikanischen Besatzung in Oberösterreich-Süd 1945-1950 (Linz: Oberösterreichisches Landesarchiv, 1995).

20. On Austria's "secret rearmament," see Bischof, Austria in the First Cold War, and idem "“Austria Looks to the West': Kommunistische Putschgefahr, geheime Wiederbewaffnung und Westorientierung am Anfang der fünfziger Jahre," in Thomas Albrich, Klaus Eisterer, Michael Gehler and Rolf Steininger, eds, Österreich in den Fünfzigern (Innsbruck: Studienverlag, 1950), 183-209; on the peculiar Austrian drafting of laws and the legislative process, see Anton Pelinka, Austria: Out of the Shadow of the Past (Boulder, CO: Westview, 1998), 50-54, and idem, "Austrian political culture: from subject to participation orientation," in Luther/Pulzer eds., Austria 1945-95, 09-120.

21. The political scientists have coined the awkward term "consociational democracy" for such across-the-board consensus politics, see Pelinka, Out of the Shadows of the Past, 22-29 and passim.

22. This is Heinz Kienzl's judgement. Through high level position in the institutions of "social partnership" and top National Bank jobs, Kienzl worked closely with most of them. See his thoughtful essay “Die starke Republik," in: Kriechbaumer, ed., Österreichische Nationalgeschichte nach $1945,469$.

23. "Future of Austria," June 8, 1944, FRUS, 1944, I, 441.

24. See the shrewd analysis of Austrian postwar anti-communism by Ingrid Fraberger and Dieter Stiefel in The Marshall Plan in Austria, (Contemporary Austrian Studies, VIII) (New Brunswick, NJ-London: Transaction, 2000), 56-69.

25. Letter Denby to Williamson, June 19, 1946, Folder: "Mission Personnel," Box 4, Lot 54 D 331 , RG 59, NA. Manfried Rauchensteiner, Die Zwei: Die Grosse Koalition in Österreich 19451966 (Vienna: Bundesverlag, 1987); idem, “Geregelte Verhältnisse? Innenpolitische Ma- 
növrierräume und ihre Spielregeln," in: Kos-Rigele, eds, Inventur 45/55, 268-286; Günter Bischof, "Between Responsibility and Rehabilitation: Austria in International Politics 1940 1950," PhD diss., Harvard University 1989, chs. 5-7 and passim, Hanisch, Der Lange Schatten des Staates, 397.

26. Ernst Hanisch, "Der forschende Blick. Österreich im 20. Jahrhundert: Interpretationen und Kontroversen," Carinthia 189 (1999): 567-583 (here 573-576).

27. For the Moscow Declaration see FRUS, 1943, I: General (Washington D.C.: GPO, 1963), 761; "Treatment of Austria," FRUS, 1944 I, 438; Peter Pulzer, "Between Collectivism and Liberalism: The Political Evolution of Austria Since 1945," in Kurt Richard Luther and Peter Pulzer, eds, Austria 1945-95: Fifty Years of the Second Republic (Aldershot: Ashgate, 1998), 229f; Bischof, Austria in the First Cold War, 52-67; Anton Pelinka, "Taboos and Self-Deception: The Second Republic's Reconstruction of History," in: Austrian Historical Memory and National Identity (Contemporary Austrian Studies, V) (New Brunswick, NJ: Transaction, 1997), 95102.

28. Friedrich Stadler, Vertriebene Vernunft I \& II: Emigration und Exil österreichischer Wissenschaft (Vienna: Jugend und Volk, 1987-1988), as well as idem, Kontinuität und Bruch.

29. One such an odyssey is retraced in the elegant essay by Egon Schwarz, "Mass Emigration and Intellectual Exile from National Socialism: The Austrian Case," in: David F. Good and Ruth Wodak, eds, From World War to Waldheim: Culture and Politics in Austria and the United States (New York: Berghahn, 1999), 87-108.

30. Marie Jahoda, 'Ich habe die Welt nicht verändert': Lebenserinnerungen einer Pionierin der Sozialforschung (Frankfurt: Campus, 1997); Raul Hilberg, The Politics of Memory: The Journey of a Holocaust Historian (Chicago: Ivan R. Dee, 1996); Walter Hölbling and Reinhold Wagnleitner, eds, The European Emigrant Experience in the U.S.A. (Tübingen: Gunther Narr, 1992); Günter Bischof, “Anglo-amerikanische Planungen und Überlegungen der österreichischen Emigration während des Zweiten Weltkrieges für Nachkriegs-Österreich,” in: Manfried Rauchensteiner and Wolfgang Etschmann, eds, Österreich 1945: Ein Ende und viele Anfänge (Graz: Styria, 1997), 17-22.

31. See the brilliant essay by Edward Timms, "Austrian Identity in a Schizophrenic Age: Hilde Spiel and the Literary Politics of Exile and Reintegration," in Luther-Pulzer, eds, Austria 194595, 55-59; Bischof, "Anglo-Amerikanische Planungen," 20f.

32. Gerard Kasemir, "Spätes Ende für 'wissenschaftlich' vorgetragenen Rassismus," in: Michael Gehler and Hubert Sickinger, eds, Politische Skandale in Österreich: Von Mayerling bis Waldheim (Thaur: Kulturverlag, 1995), 486-501.

33. Fritz Weber, Der Kalte Krieg in der SPÖ: Koalitionswächter, Pragmatiker und Revolutionäre Sozialisten 1945-1950 (Vienna: Verlag für Gesellschaftskritik, 1986); Adolf Sturmthal, Zwei Leben: Erinnerungen eines sozialistischen Internationalisten zwischen Österreich und den USA (Vienna: Böhlau, 1989); Bischof, Austria in the First Cold War, 54-56; on the continuity of anti-semitism in postwar Austria, see Bruce F. Pauley, From Prejudice to Persecution: A History of Austrian Anti-Semitism (Chapel Hill: University of North Carolina Press, 1992), $301 \mathrm{ff}$.

34. Sturmthal, Zwei Leben, 212-214.

35. Timms, "Austrian Identity in a Schizophrenic Age," 59-64 (citations from 59 and 62); on Spiel, see also Andrea Hammel, "Remembering and Forgetting: Hilde Spiel's Rückkehr nach Wien in 1946," in Bushell, ed., Austria 1945-1955, 84-98.

36. Günter Bischof, "Spielball der Mächtigen? Österreichs aussenpolitischer Spielraum im beginnenden Kalten Krieg,” in: Kos-Rigele, eds., Inventur 45/55, 133-136.

37. The best single volume on the resistance is Radomir Luza, The Resistance in Austria, 1938 1945 (Minneapolis: University of Minnesota Press, 1984); on the public mood in Vienna/the Ostmark (with OSS quotations), see Bischof, Austria in the First Cold War, 19f, and now much 
more extensively, Evan Burr Bukey, Hitler's Austria: Popular Sentiment in the Nazi Era, 19381945 (Chapel Hill: University of North Carolina Press, 2000).

38. Oliver Rathkolb, "Raoul Bumballa, ein politischer Nonkonformist 1945," in: Rudolf G. Ardelt, Wolfgang J. A. Huber and Anton Staudinger, eds, Unterdrückung und Emanzipation: Festschrift für Erika Weinzierl (Vienna: Geyer n.d.), 295-317 (quotations 305, 306).

39. Bischof, Austria in the First Cold War, 70-77; idem, "The Making of a Cold Warrior: Karl Gruber and Austrian Foreign Policy, 1945-1953," Austrian History Yearbook 26 (1995): 99127; idem, "Spielball der Mächtigen?," 126-156; see also Michael Gehler's introduction to his edition of the Gruber speeches Karl Gruber: Reden und Dokumente 1945-1953 (Vienna: Böhlau, 1994).

40. For a different trajectory in Germany see Rebecca Boehling, A Question of Priorities: Democratic Reform and Economic Recovery in Postwar Germany (Providence, R. I: Berghahn, 1996).

41. Rüdiger Overmans, "German and Austrian Losses in World War II," in: Austrian Historical Memory and National Identity (Contemporary Austrian Studies, V) (New Brunswick, NJ: Transaction, 1997), 293-301.

42. Hans Safrian, Die Eichmann-Männer (Vienna: Europaverlag, 1993; Walter Manoschek, "Serbien ist judenfrei”: Militärische Besatzungspolitik und Judenvernichtung in Serbien 1941/42 (Munich: R. Oldenbourg, 1993); Hans-Dieter Müller and Hans-Erich Volkmann, eds, Die Wehrmacht: Mythos und Realität (Munich: R. Oldenbourg, 1999).

43. Dieter Stiefel, "Nazifizierung plus Entnazifizierung $=$ Null? Bemerkungen zur besonderen Problematik der Entnazifizierung in Österreich," in: Meissl et al., eds, Verdrängte Schuld, 2836; idem, Entnazifizierugn in Österreich (Vienna: Europa Verlag, 1981); for a comparative treatment (with an essay by Stiefel on Austria), see Klaus-Dietmar Henke and Hans Woller, eds, Politische Säuberung in Europa: Die Abrechunung mit Faschismus und Kollaboration nach den Zweiten Weltkrieg (Munich: dtv, 1991).

44. "Observations by State Secretary Ernst Fischer," Herz Memorandum, August 2, 1945, in: Wagnleitner, ed., Understanding Austria, 22.

45. The Cabinet discussions are a gold mine on early discussions on denazification and the passing of the two laws; for "good Nazis," see the discussion of the 13th meeting on June 19/20, 1945, in: Protokolle des Kabinettsrates, I, 272; see also Stiefel, Entnazifizierung, and the thoughtful summary by Hanisch, Langer Schatten des Staates, 420-425, as well as the many useful cases studies of denazification of the principal Austrian institutions in Verdrängte Schuld, Verfehlte Sühne.

46. "Report on Austrian Public Opinion," March 18, 1947, in: Wagnleitner, ed., Understanding Austria, 133.

47. Ibid., 132.

48. Much of this can be inferred from the cases studies presented in Meinrad Ziegler and Waltraud Kannonier-Finster, Österreichs Gedächtnis: Über Erinnern und Vergessen der NS-Vergangenheit (Vienna: Böhlau, 1993).

49. Bischof, Austria in the First Cold War, 60-67; on "Niemals Vergessen," see Wolfgang Kos, Eigenheim Österreich: Zu Politik, Kultur und Alltag nach 1945 (Vienna: Sonderzahl, 1994); on hidebound education policies, see the thoughtful essays by Robert Knight, "Education and National Socialism after the Second World War," in: Ritchie Robertson and Edward Timms, eds, The Habsburg Legacy: National Identity in Historical Perspective (Austrian Studies V) (Edinburgh: Edinburgh University Press, 1997), 178-195.

50. Peter Utgaard, "Remembering and Forgetting the Holocaust in Austrian Schools," in: The Vranitzky Era in Austria (Contemporary Austrian Studies VII) (New Brunswick, NJ: Transaction, 1999), 201-215; on historical memory, national identity and forgetting the World War II past, see also my introduction and review essay, as well as the topical essays in Günter Bischof 
and Anton Pelinka, eds., Austrian Historical Memory and National Identity (Contemporary Austrian Studies V) (New Brunswick, NJ: Transaction, 1997), 1-13, 302-341.

51. On the restoration of the literary canon, see Anthony Bushell's introduction and the essay by Andrew Barker on von Doderer, in: Bushell, ed., Austria 1945-55, 1-110, 37, 54.

52. On the restoration of the traditional art scene, see the brilliant essay by Robert Fleck, "Kunst in einer Zeit der Restauration: Die Rekonstruktion einer Szene moderner Kunst in der österreichischen Nachkriegszeit," in Kos-Rigele, eds, Inventur 45/55, 441-471; on postwar literature, see also Wendelin Schmidt-Dengler, "Das neue Land: Die Konzeption einer neuen österreichischen Identität in der Literatur," ibid., 404-440.

53. For a sober analysis, see Dieter A. Binder, "Kontinuität - Diskontinuität: Notizen zur österreichischen Kultur nach 1945," in: Kriechbaumer, ed., Österreichische Nationalgeschichte nach 1945, 727-743 (esp. 727f, 739-741).

54. The best summary of American polls and the survival of the authoritarian mindset is Oliver Rathkolb, "NS-Problem und politische Resturation: Vorgeschichte und Etablierung des VdU," in Verdrängte Schuld, Verfehlte Sühne, 74-79; some of these polls are also published and analyzed in Wagnleinter, ed., Understanding Austria, 127-133, 333-340; for an interpretation of some of these polls, see also Hanisch, Langer Schatten des Staates, $421 \mathrm{f}$.

55. A summary of Morgenthau's report is in Oliver Rathkolb, "Hans J. Morgenthau und das Österreich-Problem in der letzten Phase der Truman-Administration 1951/52," in: Emil Brix, Thomas Fröschl and Josef Leidenfrost, eds, Geschichte Zwischen Freiheit und Ordnung (Graz: Styria, 1991), 277-298; the pupil from the 1950s is quoted in Siegfried Mattl, "Vor der IV. Republik: Politische Kultur in Österreich im 20. Jahrhundert," Zeitgeschichte 22 (January/February 1995): 39.

56. The 1989/90 polls are cited and analyzed in Bruckmüller, "Entwicklung des Österreichbewusstseins," in: Kriechbaumer, ed., Österreichische Nationalgeschichte nach 1945, 393.

57. "Report on Public Opinion," March 18, 1945, and Herz memorandum "Dangerous Tendencies in Austrian Political Thinking," October 8, 1945, in: Wagnleitner, ed., Understanding Austria, 133,54 .

58. Ibid., $53 \mathrm{f}$.

59. Ibid., $53 \mathrm{f}$.

60. American State Department records of the early 1950s are replete with Western worries about the stability of the grand coalition and the continuing necessity of American aid to keep it together in an age of imminent Cold War threats on Austria's borders. I have briefly summarized American thinking in Austria in the First Cold War, 127-129.

61. Kienzl, "Die starke Republik," in: Kriechbaumer, Österreichsiche Nationalgeschichte nach 1945, 468f.

62. Doering-Manteuffel, "Turning to the Atlantic," 15.

63. See my essay "Founding Myths and Compartmentalized Past: New Literature on the Construction, Hibernation, and Deconstruction of World War II Memory in Postwar Austria," Contemporary Austrian Studies V (1997): 302-341; an important milestone in the historical reassessment was Anton Pelinka and Erika Weinzierl, eds, Das Grosse Tabu: Östereichs Umgang mit der Vergangenheit (Vienna: Edition S, 1987); for the analysis of the larger international context of the Waldheim affair, see Richard Mitten, "Bitburg, Waldheim, and the Politics of Remembering," in: Good-Wodak, eds, From World War to Waldheim, 51-84.

64. The best analysis of these complex changes in Austrian democracy is Pelinka's fittingly entitled Austria: Out of the Shadows of the Past, op. cit. 